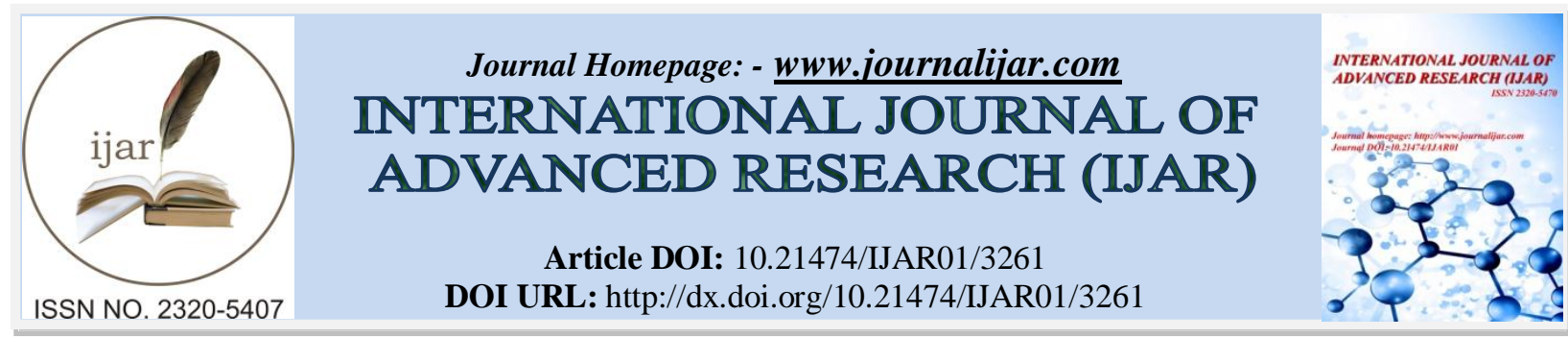

RESEARCH ARTICLE

\title{
SPIRITUAL MARKETING: A STRATEGY TO INCREASED NUMBER OF ISLAMIC BANKING CUSTOMER IN CIANJUR, WEST JAVA, INDONESIA.
}

Uus Ahmad Husaeni ${ }^{1}$ and Dadang Saepudin ${ }^{2}$.

1. Awardee LPDP and Islamic Economic and Business Faculty, Suryakancana University.

2. Islamic Economic and Business Faculty, Suryakancana University, Indonesia.

\section{Manuscript Info}

Manuscript History

Received: 16 December 2016

Final Accepted: 20 January 2017

Published: February 2017

Key words:-

Customers, Islamic Banking, Religiosity, Scholars, Sharia and Spiritual Marketing.

\section{Abstract}

The districts of Cianjur known as the city of students (santri), with $98 \%$ of the total population are Muslim. So that makes the Islamic scholar (ulama) as a central figure in deciding an issue or phenomenon that occurs in the community. Islamic banking have grown in Cianjur district, but the community's decision to choose Islamic banking in Cianjur very low. Cianjur community decision should choose Islamic banking is very high because it is motivated by the religiosity of the scholars. It's a big question for researchers, actually how much influence religiosity and scholars in an increasing number of Muslim Islamic banking customers in Cianjur. This study proves that the factor of religiosity (piety) of the Islamic scholars (ulama) has a significant effect on the increased number of customers of Islamicbanking in Cianjur. However, the scholars also insist that the procedures need to be improved, since there are still some problems in the contract that violates the principles of Sharia. One of them is the practice of mudaraba, where the Islamic banking should emphasize more in the aspect of trust instead in the aspect of insurance owned by clients or potential clients. While from the aspect of profit sharing, the Islamic banking still based its profit from the expected return rather than on the actual return. Similarly in the practice of murabahah bil wakalah, which is considered to be inconsistent in practice ( $a k a d)$. All this, eventually affect the public doubt in the aspects of Sharia compliant on Islamic banking itself. For the rational, this condition has become the reason to re-switch into conventional bank; but for the emotional, it has no effect whatsoever. Because, the condition of conventional bank used interest system (riba/usury) in practice (contradictory with principles of sharia). This study also offers solution in the form of Islamic banking marketing model accompanied with spiritual approaches. This particular approach of spiritual values is one of the most effective ways in order to increase the participation and awareness in Cianjur district to use Islamic banking in its economic activities. This research strengthen the theory of Philip Gerrard, J. Banton Cunnghen, S.A Metawa, and Almosawwi, which proves that the customers are motivated by religious factors (customers emphasized to principles of sharia loyalty) in choosing Islamic bank. The study also, at the same time, denied the theory by Norafifah Ahmad and Sudin Haron, Baeck Ulrich, and T. 
Coyle, which concluded that the motivation of customers is not influenced by religion instead on the profit calculation.

Copy Right, IJAR, 2017,. All rights reserved.

\section{Introduction:-}

Islamic economic developments in the world starting with the establishment of Islamic banking and then followed by the establishment of Islamic financial institutions. Rapid growth encourage academics in various universities conduct more in-depth studies in various forms of research, discussion, and even develop it into a course either undergraduate to doctoral. Along with the Islamic economic development that have surfaced various research results which stated that the increase in the number of customers of Islamic banking and Islamic financial institutions are motivated by factors of religiosity and material benefits (rationality), where the public insists on adherence to the principles of Islam and the benefits to be obtained.

Various studies, which states that the decision of the people choose Islamic banking and Islamic financial institutions are motivated by factors such religiosity conducted by Philip J. Gerrard and Banton Cunnghen ${ }^{[4]}$ which concluded that $22.6 \%$ of respondents from among the Muslim states that religiosity of religious reasons is the main motivation for saving money Islamic banking and Islamic financial institutions. The conclusion drawn in Muslim circles in Singapore as its object. S.A Metawa and Almosawwi ${ }^{[5]}$, this study proves that in choosing Islamic banking customers are motivated by a factor of religiosity, in which the customer stressed to compliance with the principles of Islam. Later, this conclusion is also expressed by Sehrish Rustam, Saiqa Bibi, Khalid Zaman, Adeela Rustam and Zahidul-Haq in the Perceptions of Corporate Customer toward Islamic banking Products and Services in Pakistan ${ }^{[6]}$ The conclusion of this study, stated that religiosity factors and factors of economic rationality a big influence on the selection of corporate customers in Pakistan. However, they still have less knowledge of the Islamic banks.

Meanwhile, the results of research which states that public perception to the Islamic banking and Islamic financial institutions are motivated by a gain factor of material (rationality) were performed by Norafifah Ahmad and Sudin Haron $^{[2]}$, the study concluded that the decision of the people (customers) in choosing Islamic banking not influenced religiosity or faith in religion, but more influenced by the gains in the use of bank services. Next, research conducted Ulrich Baeck ${ }^{[1]}$. The results of this research are knowledge and education more factors influence their attitudes and behavior in choosing Islamic banking, the higher the education, the knowledge and awareness of the Islamic financial system will be better. Then, the research conducted T. Coyle ${ }^{[10]}$, the results of his research concluded that the motivation of customers choose the services of Islamic banking is not influenced by religiosity but tend to be based on the profit motive.

The society decision to choose Islamic banking in Cianjur very low. Currently, customers of Islamic banking in Cianjur only about 5-8\% of the total population of 2.335 million. In fact, $98 \%$ of the population in Cianjur is Muslim. Also known as the city of students, which makes scholars as the central figure in deciding an issue or phenomenon that occurs in the community. Supposedly, the decision of the people choose Islamic banking in Cianjur will be high because motivated by factors religiosity scholars. This, the big question for researchers, actually how much influence the religiosity of scholars to the increasing number of customers of Islamic banking in Cianjur.

\section{Materials and Methods:-}

The research seeks to investigate the effect of Islamic scholar religiosity and the increased number of Islamic banking customers by using questionnaires sent to participants. The data used in this study are primary data in the form of results of a questionnaire distributed to the peoples in the district of Cianjur. The number of respondents was 100. According to Elis RatnaWulan and Uus Ahmad Husaeni ${ }^{[11]}$, that the nonprobability sampling technique was applied, in particular accidental sampling, which means sampling by coincidence, i.e., anyone who by chance met and elected to be the respondent. Data analysis techniques used in this study is as follows:

\section{Likert Scale:-}

According to Sudarmanto ${ }^{[7]}$, RS Likert developed a grading system that represents a bipolar countinum. At the left end are lower grades indicating a negative answer, while at the right end are greater numbers that indicate a positive answer. The Likert format is designed to allow customers responded in varying degrees on each item that describes services or products. The benefit of using the Likert-type format over a check list format that only provides "yes" or "no" responses is that the former accounts for the diversity of the responses for an item, ranging from 1 to 5 . This 
allows the consideration of various dimensions of perception and attitude regarding a given issue, allowing respondents to express their opinion about it.

Validity Analysis:-

According to Sudjana ${ }^{[8]}$, validity indicates the level or degree of data being used as evidence to support the conclusions drawn from the value derived from the size or scale used to measure the degree to which something is supposed to be measured. The data is said to be valid when the value corrected Item greater than the value of $r$ table with $d f=n-2$.

\section{Reliability Analysis:-}

According to Sugiono ${ }^{[9]}$, reliability is defined as the extent of measurement that is free of variance error. To estimate the reliability of the variables studied, we used Cronbach's alpha. The coefficient is generally determined with SPSS software, which is designed to be able to calculate the estimate of reliability. A variable is said to be reliable if the value of Cronbach's Alpha is $>0.6$.

\section{Correlation Analysis:-}

According to Sudjana ${ }^{[7]}$, correlation analysis is useful to assess the strength, significance, and direction of the relationship between the two variables. The direction of the relationship tested in the correlation analysis can indicate three patterns of relationships. The first pattern is a positive relationship or relationship in a unidirectional pattern; the second pattern is a negative correlation or relationship patterned in the opposite direction; and the last is where there is no pattern in the relationship. In measuring the degree of correlation, Pearson's correlation method was used and the analysis was completed through the SPSS software.

\section{Regression Analysis:-}

According to Sudarmanto ${ }^{[7]}$, regression analysis is a type of parametric analysis that can serve as a basis for predicting and analyzing the variants. Some of the objectives of regression analysis, among others, are to determine the regression line equation based on the value of the constants and the resulting regression coefficients, which indicate correlations between independent variables with the dependent variable, and to test the significance of independent variables on the dependent variable through $\mathrm{F}$. Regression analysis is used to test for correlations partially between independent variables with the dependent variable and examine the significance of independent variables on the dependent variable through the $t$-test.

\section{Results and Discussions:-}

\section{Validity and Reliability Test:-}

The validity and reliability tests were conducted to determine how many questions are valid and reliable, on the basis of a survey of 100 respondents. The results of tests on the validity and reliability of the questionnaire items are presented in table 1.

Table 1:- Operationalization Islamic Scholar Religiosity, and Increased Number of Islamic Banking Customers

\begin{tabular}{|c|c|c|c|}
\hline Variable & Item & Correlated Items & Cronbach's Alfa \\
\hline \multirow{10}{*}{ Islamic Scholar Religiosity } & $\mathrm{R} 1$ & 0.484 & \multirow{10}{*}{0.626} \\
\hline & $\mathrm{R} 2$ & 0.376 & \\
\hline & R3 & 0.434 & \\
\hline & $\mathrm{R} 4$ & 0.383 & \\
\hline & R5 & 0.373 & \\
\hline & R6 & 0.464 & \\
\hline & R7 & 0.321 & \\
\hline & $\mathrm{R} 8$ & 0.258 & \\
\hline & R9 & 0.425 & \\
\hline & R10 & 0.373 & \\
\hline \multirow{10}{*}{$\begin{array}{l}\text { Increased Number of } \\
\text { Islamic Banking Customers }\end{array}$} & I1 & 0.633 & \multirow{10}{*}{0.641} \\
\hline & $\mathrm{I} 2$ & 0.331 & \\
\hline & $\mathrm{I} 3$ & 0.651 & \\
\hline & I4 & 0.354 & \\
\hline & I5 & 0.533 & \\
\hline & I6 & 0.580 & \\
\hline & I7 & 0.558 & \\
\hline & I8 & 0.201 & \\
\hline & 19 & 0.576 & \\
\hline & $\mathrm{I} 10$ & 0.533 & \\
\hline
\end{tabular}


As shown in Table 1, all items pertaining to the variables considered were valid because the value of Cronbach's alpha was positive $(+)$ and greater than $0.1966(\mathrm{r}$ table) with $\mathrm{df}=\mathrm{n}-2$ or $\mathrm{df}=98$. The value of Cronbach's alpha for each variable was greater than 0.6 , ranging from 0.628 to 0.641 , which shows that the four variables were reliable.

\section{Correlation Analysis:-}

A close relationship was noted between Islamic scholar religiosity and increased number of Islamic banking, and the value of $\mathrm{R}$ was 0.756 . This indicated a strong correlation between the variables of Islamic scholar religiosity and increased number of Islamic banking. The positive (+) sign of the value indicates that Islamic scholar religiosity and increased number of Islamic banking have a unidirectional relationship, indicating that the higher the value of Islamic scholar religiosity, the higher the value of increased number of Islamic banking.

\section{Regression Analysis:-}

Correlation analysis of independent variable on the dependent variable was followed by regression analysis to determine the influence of independent variable on the dependent variable. The results of the regression analysis are expressed as the following regression equation:

$$
\mathrm{Y}=1,001+0,571 \mathrm{X}
$$

In regression analysis, a significant influence simultaneously or together was noted between the dependent variable and independent variable. This is evidenced by the results of the $\mathrm{F}$ test, which had a significance level of 0.000 , a value that was lower than $\alpha=0.05$. This is also supported by the results of the analysis of determination coefficient, which indicated that the independent variable in this study are related to increased number of Islamic banking customers in $57.1 \%$ of the cases, while variables other than those included in this study accounted for the remaining $42.9 \%$.

\section{Spiritual Marketing (the New Marketing of Islamic Bank):-}

Based on the results of research on the Effect of Religiosity and the Islamic Scholar Increased Number of Islamic Banking Customers in Cianjur. It can be concluded that the variables Islamic Scholar Religiosity significant effect of $57.1 \%$ on the variable Increased Number of Islamic Banking Customers. It is very interesting if the Islamic factor Scholar Religiosity was developed to increase the number of customers of Islamic banking into a new approach to the science of modern marketing. Nowadays, almost all research on Islamic banking to conclude that Islamic banking still need to be developed from various aspects and dimensions so that truly meet the expectations of not only Muslim societies but also the world community. Problems often arise about the public perception of Islamic banking are public assumes that the Islamic banking and conventional banking alike, Islamic banking do not professional services, until the assumption that the brand image of "sharia" is used by the banking industry is only a symbol and identity. A very interesting fact is people who have mistaken views and skeptical of the Islamic banking are Muslims themselves.

Therefore, the results of this study provide a basic concept of spiritual marketing for Islamic banking, the authors focus on the concept of Islamic Scholar Religiosity. Based on interviews and research directly to the public as a key informant in the study (majelis ta'lim) in parts of the district of Cianjur. The results showed that the public strongly believes the adage or advice issued by local clerics while running recitation. And the role of the clergy as a resource not only spiritual, but also serve as the policy makers in deciding a problem of individuals or groups. The scholars view that that principle of Islamic banking operations need to be improved. Because, there are still some problems in the contract that are contrary to the principles of sharia economy. One of them is the practice of mudaraba should emphasize the aspect of trust, but in reality the Islamic banking more emphasis on aspects of collateral owned by clients or potential clients. Then, from the aspect of the determination of profit sharing, Islamic banking based on the expected return and not on the actual return. Similarly, the practice of murabahah bil wakalah, which is considered to be inconsistent in the application of it contract. This, impact on the public to doubt the aspects of sharia compliant Islamic banking itself. To the rational, these conditions have an impact on the selection of another bank switching (conventional banking). However, for groups of religious emotional this condition has no effect. Because the condition of conventional banks which use the system of interest (riba/usury) in practice, so contrary to Islamic principles. They cling to one of the rules of ushul figh which is "ma la yudraku la yutrakukulluh" meaning that cannot be left entirely do everything. 
It is, to be one way Islamic banking to pursue cooperation with the Islamic scholars in Cianjur district to promote Islamic banking in order to increase the number of customers of Islamic banking increased. By way of approach of the scholars through Islamic factor Scholar Religiosity is recommending congregation or his students to become customers of Islamic banking. The scholars can be used as an alternative by Islamic banking to be the reference group in increasing the number of customers. The reference group is the group that is the size of a person's behavior shaping personality and attitude of a person to make his choice. According to Paul Peter and Jarry Olsen, there are three reference group influence, namely: information influence occurs when an individual uses the behavior and opinion of the group members as a contribution very useful information. Normative influence, sometimes referring to the utilitarian influence, occurs when the individual meets the expectations of the group to get a direct reward to avoid sanctions. Identification influence, also called value-expressive influence, occurs when an individual has experienced internalization of values and norms of the group ${ }^{[3]}$. According to investigators, spiritual approach to marketing done by the scholars to recommend congregation or its students to become customers of Islamic banks will succeed because the people in the district of Cianjur when obedient and submissive to the advice and recommendations given by the scholars.

\section{Conclusions:-}

1. Based on the research that has been discussed, it can be concluded that: Testing is done on the hypothesis (Ha) Effect of Increased religiosity are the scholars of the Islamic Banking Customers in Cianjur. Can be seen from the $t$ test resulted in the regression test $t$ count $>t$ table (11.416> 3.94) thus proving the hypothesis (Ha) is accepted and the coefficient of determination (R2) of 0.571 or $57.1 \%$

2. Based on interviews and research directly to the public as a key informant in the study (majelis ta'lim) in parts of the district of Cianjur. The results showed that the public strongly believes the adage or advice issued by local clerics while running recitation. The role of the clergy as a resource not only spiritual, but also serve as the policy makers in deciding a problem of individuals or groups. By way of approach of the scholars through Islamic Scholar Religiosity factor is recommending congregation or his students to become customers of Islamic banking. The scholars can be used as an alternative by Islamic banking to be the reference group in increasing the number of customers using the spiritual marketing concept.

\section{Acknowledgment:-}

The first author would like to thank LPDP for providing the research grant, Graduate School State Islamic University of Syarif Hidayatullah Jakarta, and the Faculty of Economic and Business Suryakancana University for supporting in this research. The second author wish to thank Faculty of Economic and Business Suryakancana University for moral supporting in this research.

\section{References:-}

1. Baeck Ulrich. 2008.Risk Society: Toward a New Modernity, Sage Publication, London and Newbury Park

2. Norafifah Ahmad dan Sudin Haron. 2002). Perception of Malaysian Corporate Customer toward Islamic Banking Product and Service, International Journal of Islamic Financial Service. 3 (4). 13-29.

3. Paul Peter dan Jarry L. Olsen. 1999. Customer Behaviour, Prilaku Konsumen dan Strategi Pemasaran, Erlangga, Jakarta.

4. Philip Gerrard dan J. Banton Cunnghen. 2015. Islamic Banking, A Study in Singapure, International Journal of Marketing Bank. 23 (1), 73-80.

5. S.A Metawa dan Almosawwi. (2008). Banking Behavior of Islamic Bank Customer Perspective, International Journal of Marketing Bank. 16 (7). 299-313.

6. Sehrish Rustam, Saiqa Bibi, Khalid Zaman, Adeela Rustam dan Zahidul-haq. (2011). Perceptions of Corporate Customer toward Islamic Banking Product and Services in Pakistan, The Romanian Economic Journal, 17 (41), 107119.

7. Sudarmanto, R.G. 2005. Analisis Regresi Linier Berganda dengan SPSS. Yogyakarta: Graha Ilmu.

8. Sudjana. 2001. Metode Statistika. Bandung: Tarsito.

9. Sugiyono. 2008. Metode Penelitian Bisnis (Pendekatan Kuantitatif, Kualitatif, dan R \& D). Bandung: Alfbeta.

10. T. Coyle. 1999. The Banking of Tomorrow, American Community Banker, 8 (7), 63-72.

11. Wulan, Elis, Ratna., Ahmad, Uus, Husaeni. (2015). Analysis of the Variables that Affect Bookstore Customer Satisfaction. International Journal of Nusantara Islam. 03 (02). 27-36. 